\title{
78. DIATOM BIOSTRATIGRAPHY, DEEP SEA DRILLING PROJECT LEG 37
}

\author{
Hans-Joachim Schrader, Geologisch-Paläontologisches Institut und Museum \\ der Universität Kiel, 23 Kiel, F.R. Germany
}

\section{INTRODUCTION}

The prime objective of Leg 37 was an investigation of acoustic basement, thus most of the sediment column was spot cored (see Figure 1 for location of drill sites). Light-microscope techniques were used to examine the diatom flora and sponge spicules in 91 samples from these cores. For detailed description of sample preparation, light microscopical examination, and biostratigraphic subdivision see Burckle (1972), Schrader (1973a, 1974), Schrader and Burckle (in press). The occurrences of diatom species are tabulated in Table 1 for all six holes, and biostratigraphic interpretation is listed separately under each hole.

\section{DIATOM SITE SUMMARIES}

Table 1 illustrates the occurrence of marine planktonic, marine benthonic, and fresh-water diatoms from material recovered during Leg 37 . The following abbreviations are applied to species abundance and preservation: $\mathrm{P}$ (poorly preserved), $\mathrm{M}$ (moderately well preserved), G (well preserved), A (abundant), C (common), F (few), R (rare), T (trace amounts), and ? (questionable identification). Species which are interpreted as reworked are marked with a circle around the abundance designation.

Holes 332, 332A, and 332B (lat $36^{\circ} 52.72 ' \mathrm{~N}$, long $33^{\circ} 38.46^{\prime} \mathrm{W}$, water depth $1818 \mathrm{~m}$ )

The two samples available from Hole 332 are barren of diatoms (Table 1). The 15 samples from Hole 332A contain a moderately to well preserved diverse diatom assemblage of tropical character of Quaternary to Pliocene age. Admixtures of airborne fresh-water diatoms are rare, but sponge spicules are present. Sediment samples below Core 5 are barren of diatoms. The oldest diatom-bearing sediment $(5-5,58-60 \mathrm{~cm})$ is early Pliocene (approximately 3.3 to 4.3 m.y.B.P.). The joint occurrence of Nitzschia jouseae and Thalassiosira convexa in Samples $1-1,70-72 \mathrm{~cm}$ to $2-2,80-82 \mathrm{~cm}$ (7.5 to $66 \mathrm{~m}$ subbottom) places this interval into the Nitzschia jouseae Partial-Range Zone of Burckle (1972), which has a middle/late early Pliocene age.

On the other hand this interval could be correlated with the equatorial Indian Ocean zonation (Schrader, 1974) TID Zone 9, which has been dated through indirect correlation with the paleomagnetic stratigraphy and the absolute time scale of Berggren (1972) as being of 2.85 m.y.B.P. to slightly older.

The sediment sequence from Sample 2-3, $70-72 \mathrm{~cm}$ to $5-5,58-60 \mathrm{~cm}$ is placed into the Thalassiosira convexa Partial Range Zone of Burckle (1972) which is of late
Miocene to early Pliocene age. Using the tropical Indian Ocean scheme, this interval can be allied to TID Zones 10-12, which have been dated through indirect correlation as being approximately 3.3 to 4.3 m.y.B.P.

The five samples available from Hole 332B contain a moderately to well preserved diverse tropical diatom assemblage. No admixtures of fresh water and/or displaced marine benthonic diatom species were found. The oldest recovered diatom-bearing sediment (Sample $1-5,12-14 \mathrm{~cm}$ ) is of late Pliocene age (approximately 1.8-2.9 m.y.B.P.).

The joint occurrence (Table 1) of Rhizosolenia praebergonii, Thalassiosira convexa, and Nitzschia jouseae places this interval $(142-148 \mathrm{~m})$ into the Rhizosolenia praebergonii Partial Range Zone of Burckle (1972), which has been dated by direct correlation to the paleomagnetic stratigraphy and radiometric time scale (Berggren, 1972; Cox, 1969) as being 1.8-2.9 m.y.B.P. This zone has been subdivided by Burckle (1972) into three subzones-A, B, and C. Subzone A (oldest) is characterized by the joint occurrence of Thalassiosira convexa, Nitzschia jouseae, and Rhizosolenia praebergonii and the top by the last appearance of Nitzschia jouseae (this evolutionary event is found in Hole 332B at approximately 1-4, 35-37 $\mathrm{cm})$. Subzone B is characterized by the joint occurrence of Rhizosolenia praebergonii and Thalassiosira convexa with the top defined by the last appearance of Thalassiosira convexa. The disappearance of Thalassiosira convexa was not observed in the present material, therefore an age of approximately 2.1 m.y.B.P. or older can be postulated for the youngest sample. Precise sediment accumulation rates cannot be obtained from the available data. However, rates changed considerably between middle and early Pliocene (Figure 2).

\section{Hole 333 (lat $36^{\circ} 50.45^{\prime} \mathrm{N}$, long $33^{\circ} \mathbf{4 0 . 0 5}^{\prime} \mathrm{W}$, water depth $1665.8 \mathrm{~m}$ )}

The samples obtained above Core 6 contain a moderately to well preserved diverse tropical diatom flora of Pliocene age. Admixtures of displaced benthonic diatoms were found in Sample 5-2, 70-72 cm with Rhaphoneis amphiceros, Diploneis sp.; no freshwater species were found. Sponge spicules are common in some intervals (Table 1). The oldest diatom-bearing sediment $(6-1,70-72 \mathrm{~cm})$ is of middle Pliocene age (approximately $2.8-4.3$ m.y.B.P.).

The sediment interval between Samples 2-1, 70-72 cm and 4-1, 70-72 $\mathrm{cm}$ (146 to $184 \mathrm{~m}$ ) can be correlated with the Rhizosolenia praebergonii Partial Range Zone of Burckle (1972) by the joint occurrence of Rhizosolenia 


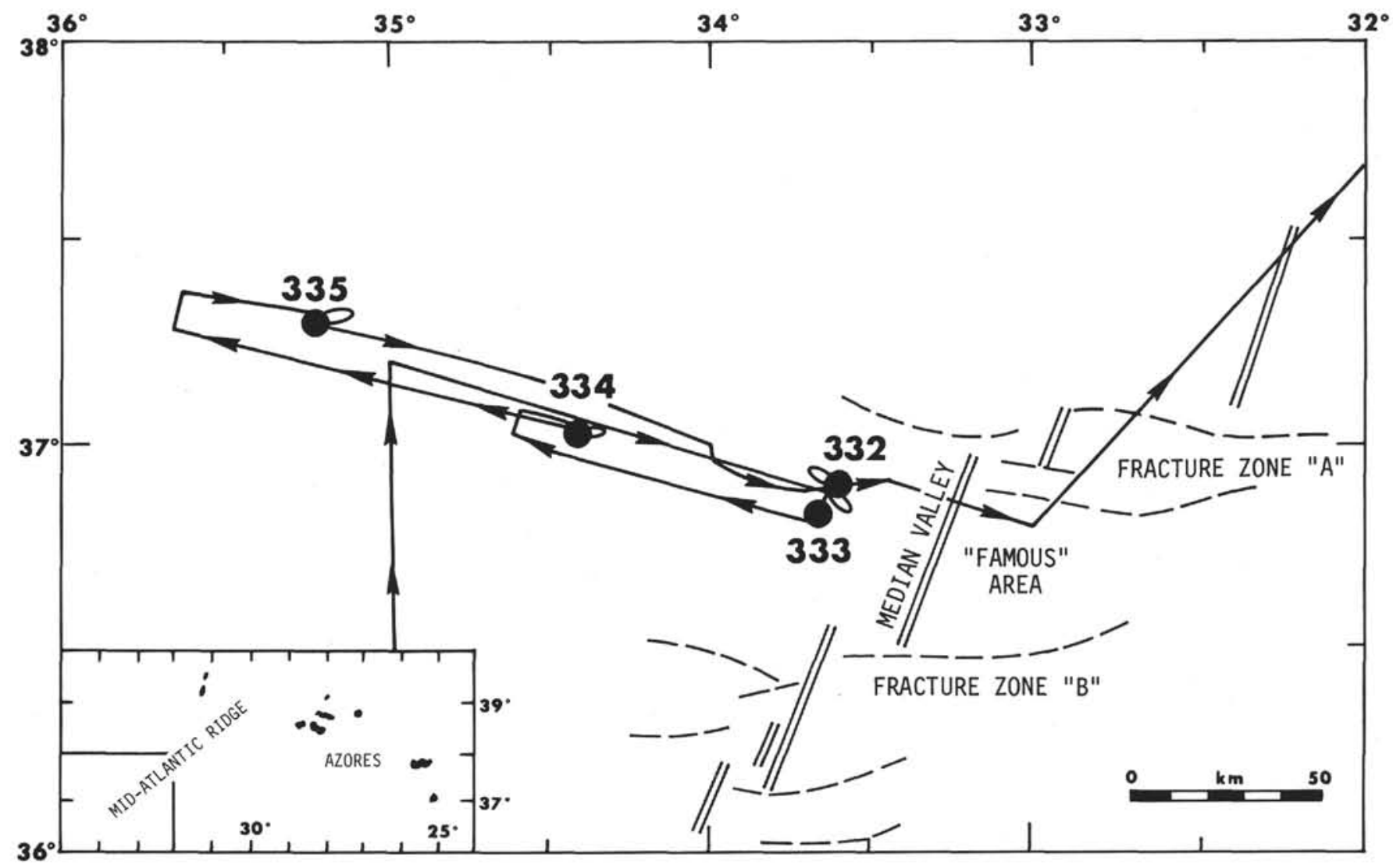

Figure 1. Location of drilling sites, Leg 37 Deep Sea Drilling Project, Mid-Atlantic Ridge.

praebergonii (present in Samples 3-4, 68-70 through 4-1, $70-72 \mathrm{~cm}$ ) and Thalassiosira convexa. These occurrences place this interval into Subzone B (Burckle, 1972), correlative with Tropical Indian Ocean Zone 7 of Schrader (1974) which is approximately 2.1-2.4 m.y.B.P. in age.

The sediment interval between Samples 4-2, $70-72 \mathrm{~cm}$ and $4-4,70-72 \mathrm{~cm}$ (186 to $188.5 \mathrm{~m}$ ) can be assigned to the Rhizosolenia praebergonii Partial Range Zone, Subzone B of Burckle (1972), by the joint occurrence of Nitzschia jouseae and Thalassiosira convexa. Rhizosolenia praebergonii was not found. Subzone B is correlative in its lower part to Tropical Indian Ocean Zone 8 of Schrader (1974) which is approximately 2.42.8 m.y.B.P. in age.

The interval between Samples 4-5, 70-72 $\mathrm{cm}$ and 6-1, $70-72 \mathrm{~cm}(190-203 \mathrm{~m})$ can be assigned to the Nitzschia jouseae Partial Range Zone of Burckle (1972), which is of middle Pliocene (2.8-4.3 m.y.B.P.). No further detailed stratigraphic subdivision was possible. Sediment accumulation rates are on the order of 7.4 to 1.2 $\mathrm{cm} / 1000 \mathrm{yr}$ (Figure 3).

\section{Site 334 (lat $37^{\circ} 02.13$ ' , long $34^{\circ} 24.87^{\prime} \mathrm{W}$, water depth $2632 \mathrm{~m}$ )}

Samples from Core 1 yielded a poorly preserved diatom assemblage with no age-diagnostic key taxa. Samples derived from Cores 2 and 3 were barren of diatoms. Cores 4 through 12 contain a diverse tropical diatom flora with varying preservation, ranging from poorly to well preserved. Displaced fresh-water dia- toms of the species Melosira granulata were observed only in Sample 11-2, 68-70 cm. Core 14 contained only sporadic occurrences of poorly preserved diatom frustules with no age diagnostic key species. The oldest recovered diatom-bearing sediment $(13-2,112-114 \mathrm{~cm})$ is of early late Miocene age.

Samples 4-1, 70-72 cm to 7-1, 70-72 cm (149-177.5 m) contain common Nitzschia porteri Frenguelli (for taxonomy see Schrader, 1974), Nitzschia marina, Nitzschia cylindrus, Nitzschia fossilis, and Nitzschia praereinholdii. Nitzschia marina has an expanded range compared to occurrences in the east equatorial Pacific where the first occurrence is within paleomagnetic epoch 6 (Cox, 1969) and is correlative with the upper part of the Nitzschia miocenica Partial Range Zone of Burckle (1972). The joint occurrence of the abovementioned key taxa places this interval in the upper part of the Nitzschia porteri Partial Range Zone of Burckle (1972), which in turn is correlative with the lower part of paleomagnetic epoch 7 with an age of 7.28.1 m.y. B.P. The interval from Samples $5-2,71-73 \mathrm{~cm}$ to $12-2,67-69 \mathrm{~cm}(160-226 \mathrm{~m})$ contains common Thalassiosira burckliana (synonym Thalassiosira sp. A in Burckle, 1972) and covers the lower part of the Nitzschia porteri Partial Range Zone of Burckle (1972) (approximately at the boundary of paleomagnetic epochs 7 and 8), and the upper part of the Coscinodiscus yabei Partial Range Zone of Burckle (1972), equivalent to the upper part of paleomagnetic epoch 9 . Thalassiosira burckliana ranges in tropical Indian 


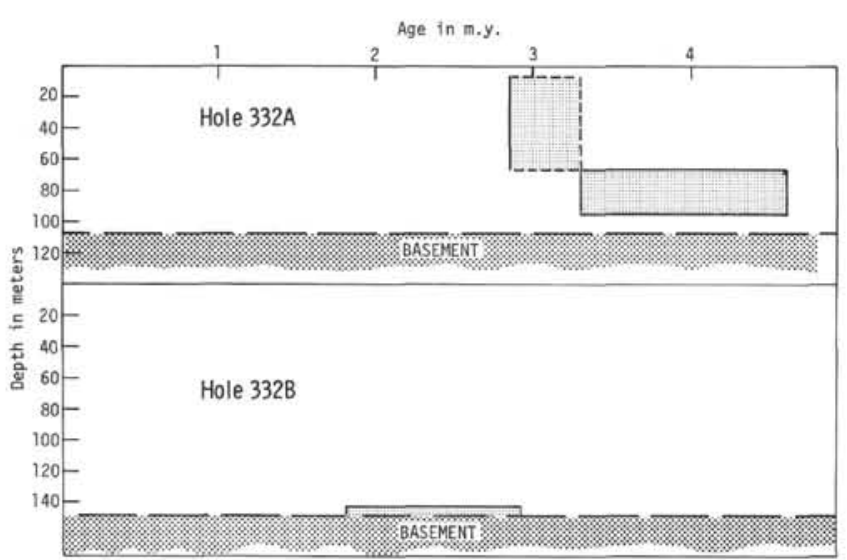

Figure 2. Sediment accumulation rate, Holes $332 A$ and $332 B$.

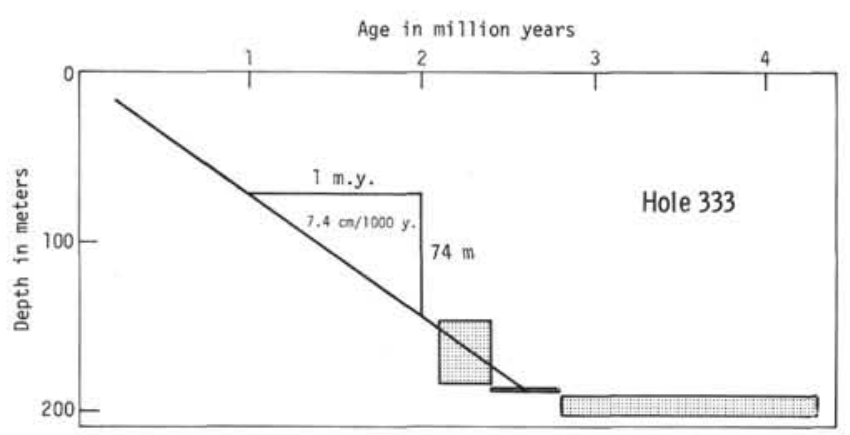

Figure 3. Sediment accumulation rate, Hole 333.

Ocean sediments from TID Zone 19 through the upper part of TID Zone 20. These zones are correlated to the paleomagnetic stratigraphy and through indirect correlation to the radiometric time scale. They are approximately 8.1-9 m.y.B.P. Denticula hustedtii has an expanded range in tropical sediments here compared to its range in the Indian and Pacific oceans; there its last occurrence is below the first occurrence of Thalassiosira burckliana. On the other hand Denticula hustedtii ranges through most of the Late Miocene in Neogene sediments, and is representative of cold biofacies (Schrader, 1973a, 1973b). The last occurrence of members of the Coscinodiscus plicatus group (including Coscinodiscus yabei and Coscinodiscus plicatus) was found at Site 334 in Sample 8-2, 110-112 cm. Therefore the upper boundary of the Coscinodiscus yabei Partial Range Zone of Burckle (1972) is placed at this level (approximately 8.5 m.y.B.P.) The range of Coscinodiscus aeginensis supports this placement. This species ranges in Neogene equatorial Pacific sediments slightly over this boundary. The first occurrence of Coscinodiscus aeginensis was found here in Sample 8-1, 122-124 cm $(187.5 \mathrm{~m})$. The interval below Sample 12-2, 67-69 cm has only a moderately to poorly preserved diatom assemblage and is tentatively assigned to the Coscinodiscus yabei Partial Range Zone of Burckle (1972). It still is of early late Miocene age because "modern" Nitzschia species are present. Sediment accumulation rates are on the order of 2.4 to $4.0 \mathrm{~cm} / 1000$ yr (Figure 4).

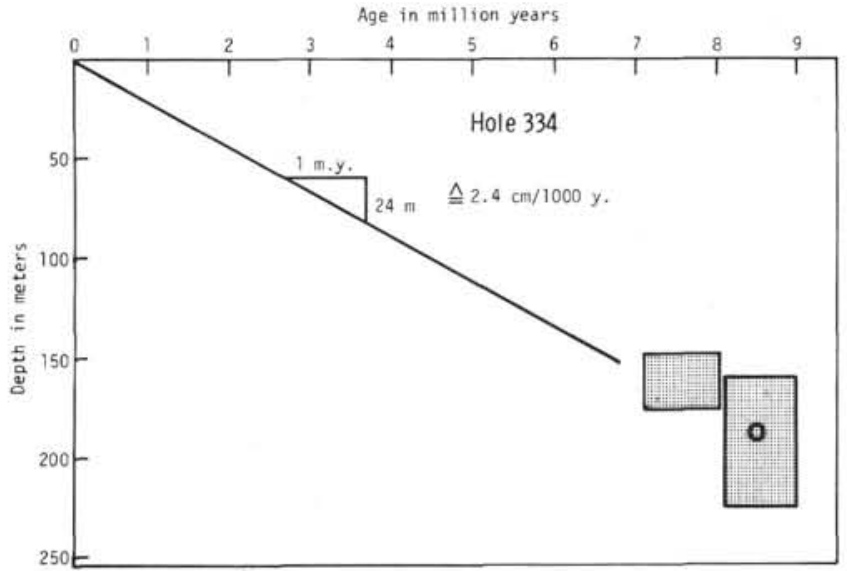

Figure 4. Sediment accumulation rate Site 334.

Site 335 (lat $37^{\circ} 17.14^{\prime} \mathrm{N}$, long $35^{\circ} 11.92^{\prime} \mathrm{W}$, water depth $3198 \mathrm{~m}$ )

Samples from Cores 1 through 5 contain a well to poorly preserved diverse tropical diatom flora with an interval being barren in opal. Displaced, airborne freshwater diatoms, including the key taxa Melosira granulata, were observed sporadically in Cores 1 and 4; no displaced marine benthonic diatom species were found. Sponge spicules are abundant in the moderately well preserved diatom assemblages due to enrichment by selective dissolution (Table 1). The oldest recovered diatom-bearing sediment (Sample 5-1, 132-134 cm, 449 $\mathrm{m}$ ) is of late middle Miocene (approximately 11.4-13 m.y.B.P.)

Core 1 contains common Pseudoeunotia doliolus associated with "modern" species of the genus Thalassiosira ( $T$. decipiens, $T$. oestrupii e.g.) and is therefore placed in the Pseudoeunotia doliolus Range Zone of Burckle (1972), which is of Pleistocene age (01.8 m.y.B.P.). More precise age assignment is possible through the co-occurrence of Nitzschia reinholdii which becomes extinct in tropical Indian Ocean sediments at the base of TID Zone 1 (Schrader, 1974a) and which has an extrapolated age of 0.4 m.y.B.P.

The interval between Core 2 through Sample 4-3, 70$72 \mathrm{~cm}$ contains only a poorly preserved diatom assemblage with no biostratigraphic key taxa. Sample $5-1,132-134 \mathrm{~cm}(449 \mathrm{~m})$ does contain a well-preserved diversified Miocene tropical assemblage with common Denticula punctata, D. punctata var. hustedtii, D. hustedtii, Coscinodiscus temperei, Macrora stella, and Mediaria splendida. This sample can be placed into the Cussia paleacea Partial Range Zone of Schrader and Burckle (in press) and ranges from the uppermost part of paleomagnetic epoch 14 to the middle of paleomagnetic epoch 12 (approximately 11.4-13 m.y.B.P.) and is of late middle Miocene age. The tropical Indian Ocean diatom zonation does not cover the middle/late Miocene boundary thus no correlation to that zonation is possible. On the other hand, similar floras were found below TID Zone 21 at DSDP Site 238, which have been correlated by Vincent (1974) to zones N15-N14 of the standard planktonic foraminiferal zonation. Sediment accumulation rates 
TABLE 1

Distribution of Diatoms and Other Siliceous Microfossils at Sites 332, 333, 334, and 335 Sample
(Interval in $\mathrm{cm}$ ) 332-1-1, 124-126 $332-1-3,120-122$ $332 \mathrm{~A}-1-1,70-72$ 332A-1-1, 94-96 332A-2-2, 80-82 $332 \mathrm{~A}-2-3,70-72$ $332 \mathrm{~A}-2-4,63-65$ $332 \mathrm{~A}-2-5,58-60$ $332 \mathrm{~A}-3-3,90-92$ $332 \mathrm{~A}-4-4,34-36$ $332 \mathrm{~A}-4-5,30-32$ $332 \mathrm{~A}-5-3,133-135$ $332 \mathrm{~A}-5-4,34-36$ 332A-5-5, 28-30 332A-5-5, 58-60 332A-6-1, 79-81 $332 \mathrm{~A}-6-2,60-62$ $332 \mathrm{~B}-1-1,60-62$ 332B-1-2, 38-40 332 B-1-3, 135-13 332B-1-4, 35-37 $\frac{332 \mathrm{~B}-1-5,12-14}{333-2-1,70-72}$ $333-2-2,70-72$ 333-2-3, 70-71 333-2-4, 70-72 $333-2-5,56-59$ 333-2-6, 70-72 333-3-1, 70-72 333-3-2, 70-72 333-3-3, 70-72 333-3-4, 68-70 333-3-6, 70-72 333-4-1, 70-72 333-4-2, 70-72 333-4-3, 70-72 $333-4-4,70-72$ $333-4-5,70-72$ $333-5-2,70-72$

C 1 B

\begin{tabular}{ll|l}
$\mathrm{B}$ & $\overline{\mathrm{G}}$ & $\mathrm{R}$
\end{tabular}

$\begin{array}{cccc}\text { C } & \text { B } & - \\ \text { C } & \text { A } & \text { G } & \text { R } \\ & & \text { A } & \text { G }\end{array}$

$\begin{array}{llll}A & G & R \\ \text { A } & G & R\end{array}$

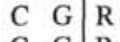

C C G R

$\begin{array}{llllllll}\text { C } & & \text { B } & - & & \\ \text { B } & & \text { A } & \text { G } & \text { R } & \text { R }\end{array}$

\begin{tabular}{ll|ll} 
A & G & R & R \\
C & G & & R
\end{tabular}

$\begin{array}{llll}\mathrm{F} & \mathrm{M} & \mathrm{R}\end{array}$

$\begin{array}{lllll}\mathrm{F} & \mathrm{C} & \mathrm{M} & \mathrm{R}\end{array}$

C

$\begin{array}{ll}\mathrm{F} & \mathrm{M} \\ \mathrm{F} & \mathrm{M}\end{array}$

$\begin{array}{ll}\mathrm{A} & \mathrm{B} \\ \mathrm{A} & \mathrm{B}\end{array}$

\begin{tabular}{lll|l} 
C & C & G & R \\
A & C & G & R
\end{tabular}

C $G$

\begin{tabular}{ll|l}
$C$ & $M$ & \\
C & $G$ & $R$
\end{tabular}

R A G

A $G$

C $\quad$ C $\mathrm{G}$

C A G

$\begin{array}{ll}\text { A } & \text { G } \\ \text { A } & \end{array}$

A $M$

A $\quad$ A $G$

\begin{tabular}{lll} 
& A & $G$ \\
A & C & M \\
\hline
\end{tabular}

$\begin{array}{lll}\mathrm{R} & \mathrm{M} \\ \mathrm{C} & \mathrm{C} & \mathrm{M}\end{array}$

$\begin{array}{lll}\mathrm{C} & \mathrm{C} & \mathrm{M} \\ \mathrm{C} & \mathrm{R} & \mathrm{M}\end{array}$

C $\quad \mathrm{R} \quad \mathrm{M}$

C $\mathrm{M}$

$\left|\begin{array}{lll} & \mathrm{C} & \mathrm{M} \\ \mathrm{C} & \mathrm{C} & \mathrm{M}\end{array}\right|$

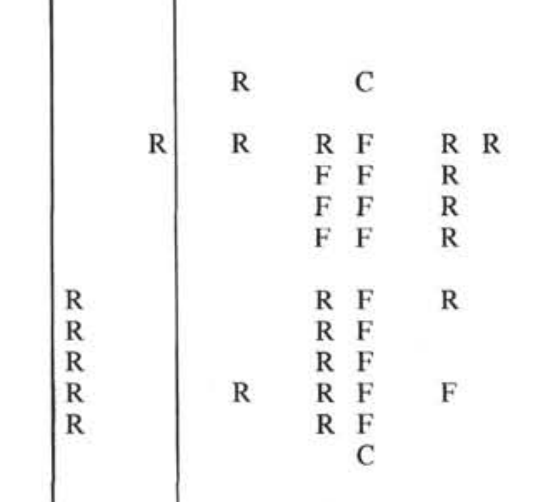

\begin{tabular}{r|r}
$\mathrm{R} \mathrm{F}$ \\
$\mathrm{R} \mathrm{F}$
\end{tabular}

$\begin{array}{ll}\mathrm{R} & \mathrm{F} \\ \mathrm{R} & \mathrm{F}\end{array}$

$\begin{array}{ll}R & F \\ R & F\end{array}$ $\begin{array}{ll}\mathrm{R} & \mathrm{C} \\ \mathrm{R} & \mathrm{C}\end{array}$

\begin{tabular}{ll}
$\mathrm{R}$ & $\mathrm{C}$ \\
\hline & $\mathrm{R}$
\end{tabular}

$\begin{array}{llll}\mathrm{R} & \mathrm{R} & \\ \mathrm{R} & \mathrm{F} & \mathrm{R}\end{array}$

$\begin{array}{lll}\mathrm{R} & \mathrm{F} & \mathrm{R} \\ \mathrm{R} & \mathrm{F} & \mathrm{R}\end{array}$

R $\mathrm{F} \quad \mathrm{R}$

R F R

$\begin{array}{lll}\mathrm{F} & \mathrm{F} \\ \mathrm{F}\end{array}$

$\mathrm{R}$
$\mathrm{R}$

$\begin{array}{lll} & \mathrm{C} & \mathrm{R} \\ \mathrm{R} & \mathrm{C} & \mathrm{R}\end{array}$

R F

R F

R F

$\begin{array}{ll}\mathrm{R} & \mathrm{F} \\ \mathrm{R} & \mathrm{F}\end{array}$

R F

$\begin{array}{lll}\mathrm{R} & \mathrm{F} & \\ \mathrm{R} & \mathrm{C} & \mathrm{R}\end{array}$

(2)

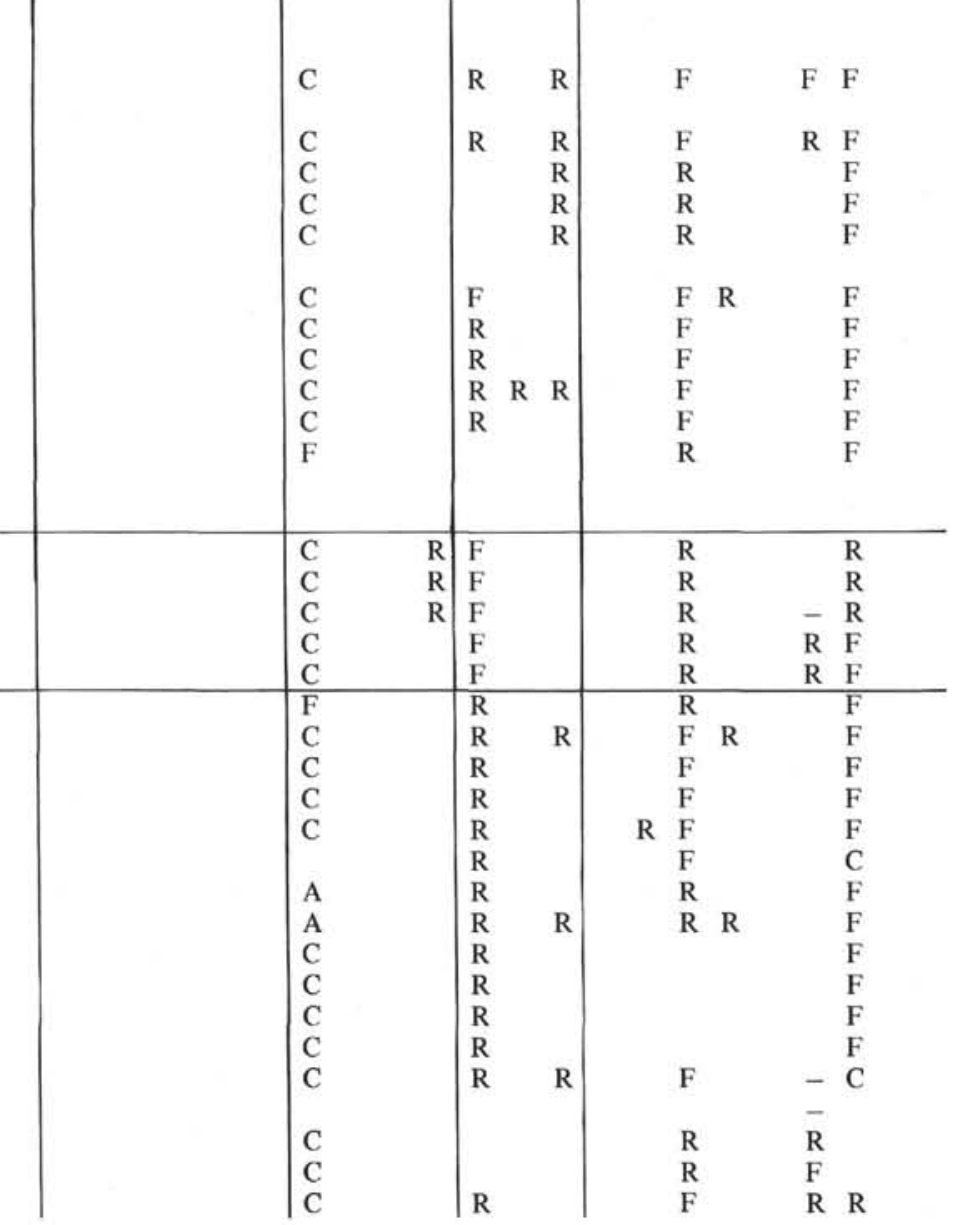




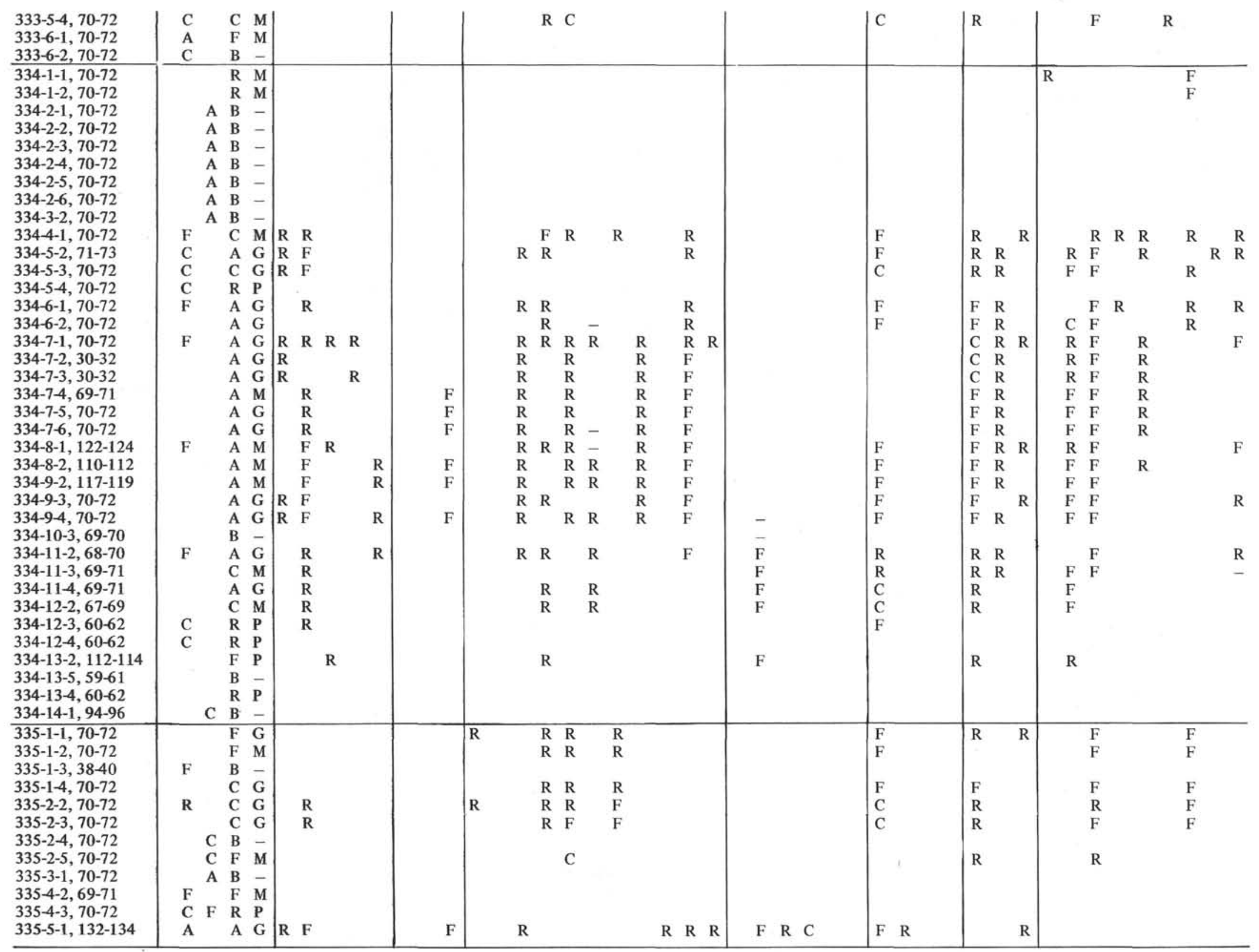


Sample

$332-1-1,124-126$

$332-1-3,120-122$

332A-1-1, 70-72

$332 \mathrm{~A}-1-1,94-96$

$332 \mathrm{~A}-2-2,80-82$

332A-2-3, 70-72

$332 \mathrm{~A}-2-5,58-60$

$332 \mathrm{~A}-3-3,90-92$

$332 \mathrm{~A}-4-4,34-36$

$332 \mathrm{~A}-4-5,30-32$

332A-5-3, 133-135

$332 \mathrm{~A}-5-4,34-36$

$332 \mathrm{~A}-5-5,28-30$

$332 \mathrm{~A}-5-5,58-60$

$332 \mathrm{~A}-6-1,79-81$

$332 \mathrm{~A}-6-2,60-62$

332B-1-1, 60-62

332B-1-2, 38-40

332B-1-3, 135-137

332B-1-4, 35-37

$332 \mathrm{~B}-1-5,12-14$

$333-2-1,70-72$

$333-2-2,70-72$

$333-2-4,70-72$

$333-2-4,70-72$

$333-2-6,70-72$

$333-3-1,70-72$

$333-3-2,70-72$

333-3-3, 70-72

$333-3-4,68-70$

333-3-6, 70-72

$333-4-1,70-72$

333-4-2, 70-72

$333-4-3,70-72$

$333-4-4,70-72$

$333-4-5,70-72$

$333-5-2,70-72$

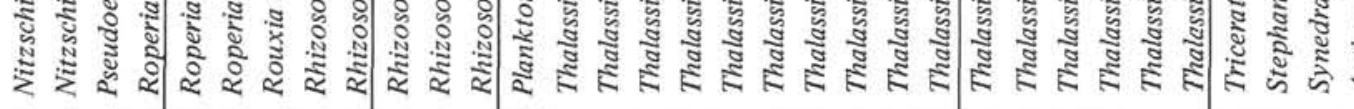

<

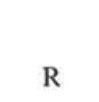

$\begin{array}{ll}R & R \\ R & R \\ & R \\ & R \\ & R \\ R & R \\ & F \\ & F \\ & R \\ & F\end{array}$

$\begin{array}{llll} & & & \\ \mathrm{F} & \mathrm{R} & \mathrm{F} & \mathrm{F} \\ & \mathrm{R} & \mathrm{F} & \\ \mathrm{F} & \mathrm{F} & \\ \mathrm{F} & \mathrm{F} & \\ \mathrm{F} & \mathrm{F} & \\ \mathrm{R} & \mathrm{F} & \mathrm{R} ? \\ \mathrm{~F} & \mathrm{R} & \\ \mathrm{F} & \mathrm{R} & \\ \mathrm{R} & \mathrm{R} & \\ \mathrm{F} & \mathrm{R} & \mathrm{F}\end{array}$

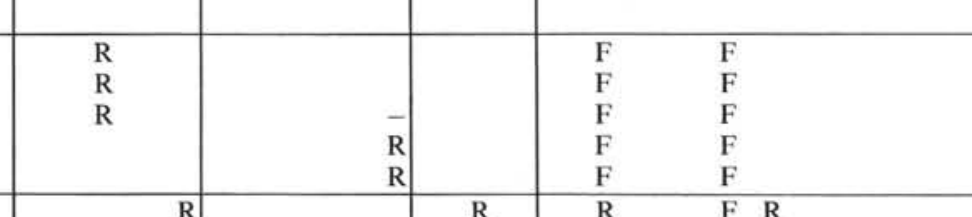

$\mathrm{R}$
$\mathrm{R}$

$\mathrm{R} \quad \mathrm{R}$

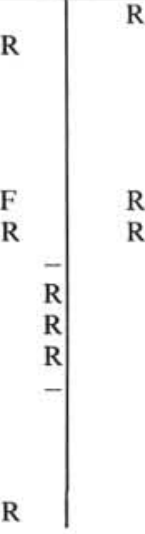

$\begin{array}{llll}\mathrm{F} & & & \\ \mathrm{F} & \mathrm{R} & & \\ \mathrm{F} & \mathrm{R} & \mathrm{R} & \mathrm{F}\end{array}$

R $\mathrm{A}$

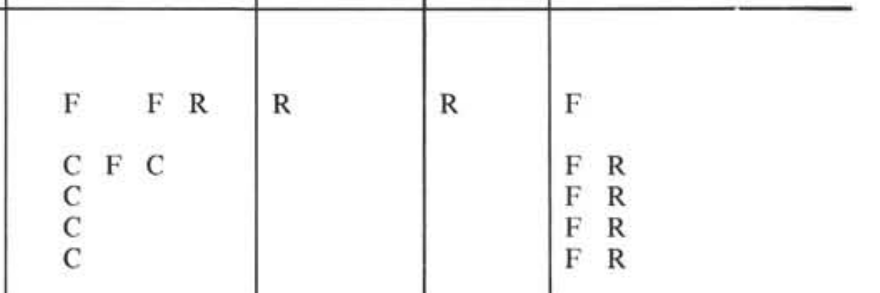

$\begin{array}{ll}\mathrm{F} & \mathrm{R} \\ \mathrm{F} & \mathrm{R} \\ \mathrm{F} & \mathrm{R}\end{array}$

\begin{tabular}{l|l}
$\mathrm{R}$ & $\mathbf{F}$ \\
$\mathrm{R}$ & $\mathbf{R}$
\end{tabular}

$\mathrm{R}$

$\begin{array}{ll}\mathrm{F} & \mathrm{R} \\ \mathrm{F} & \end{array}$

$R$

$\begin{array}{llll}R & C & C & F \\ R & C & & F \\ R & C & & F \\ R & C & F & F\end{array}$

$\begin{array}{llll}R & C & F & F \\ R & C & & F\end{array}$

$\begin{array}{llll}\mathrm{R} & \mathrm{C} & \mathrm{F} & \\ \mathrm{C} & & \mathrm{F}\end{array}$

$\mathrm{R}$
$\mathrm{R}$

$\mathrm{R}$

$\begin{array}{lllll}R & A & C & C & R\end{array}$

$\begin{array}{ll}R & C \\ R & C\end{array}$

$\begin{array}{ll}R & C \\ R & C\end{array}$

$\begin{array}{ll}\mathrm{R} & \mathrm{C} \\ \mathrm{R} & \mathrm{C}\end{array}$

$\begin{array}{lll}\mathrm{R} & \mathrm{C} & \\ & \mathrm{C} & \mathrm{R}\end{array}$

\begin{tabular}{|ll|l|l|l|l|l} 
& & & & & \\
& & & \\
R & $C$ & F & R \\
R & R & F
\end{tabular} 


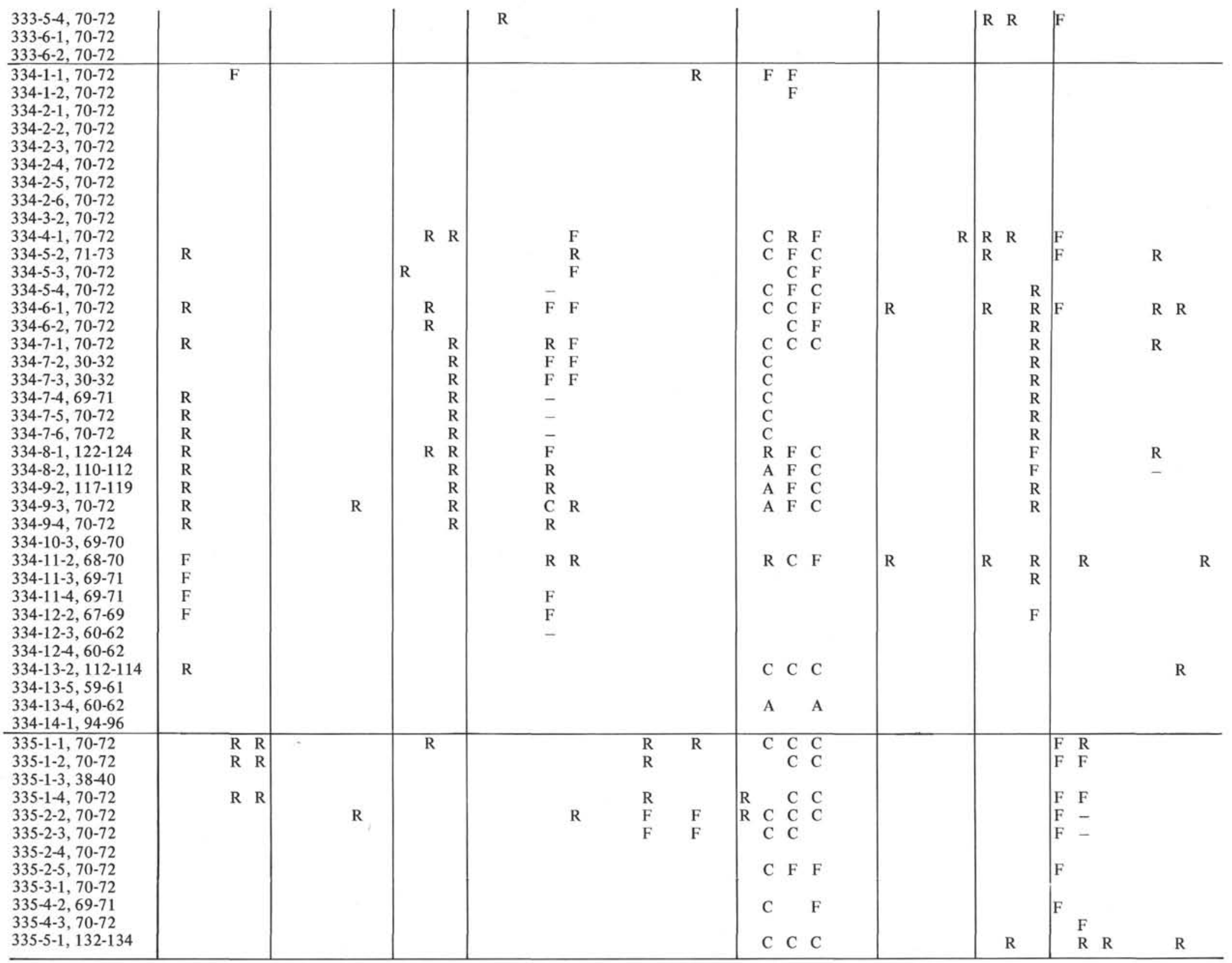


are on the order of $3.5 \mathrm{~cm} / 1000 \mathrm{yr}$ for the late Miocene/Pliocene interval (Figure 5).

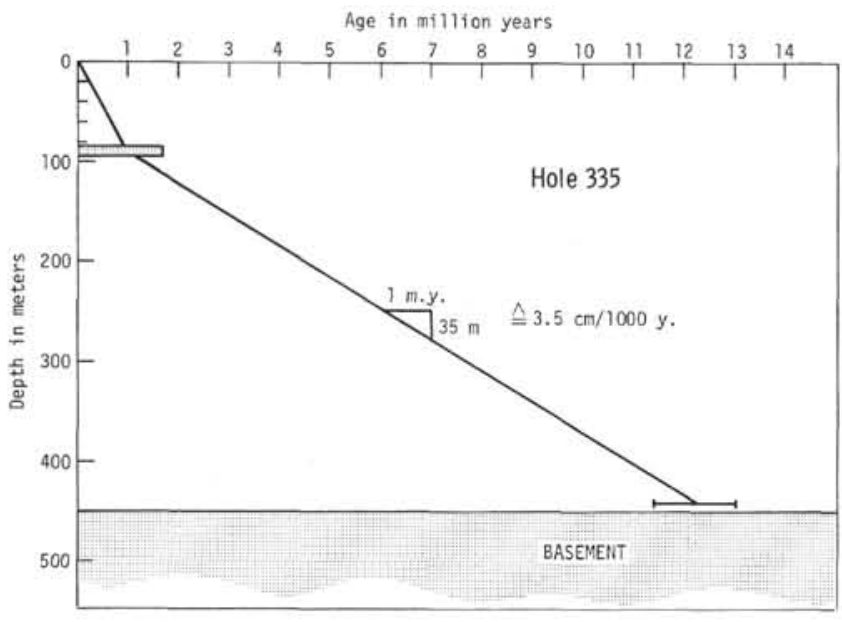

Figure 5. Sediment accumulation rate, Site 335.

\section{CONCLUSIONS}

1. Table 2 summarizes the diatom zonation used in this paper and numbers assigned to zones represent the cores and their 1.5-meter sections.

2. Occurrences of diatoms (dotted left lines) and occurrences of displaced fresh-water diatoms (triangles on right sides) are summarized on Figure 6.

3. The applicability of the established diatom zones of the east equatorial Pacific and the tropical Indian Ocean has been tested and nearly the same type of key species can also be used in the Atlantic.

4. Spreading rates of Leg 37 sites using biostratigraphic data are as follows: Site 332A: 1.03-0.79 cm/yr, Site 332B: $1.83-1.17 \mathrm{~cm} / \mathrm{yr}$, Site $333: 1.23-0.8 \mathrm{~cm} / \mathrm{yr}$, Site 334: $1.15 \mathrm{~cm} / \mathrm{yr}$, and Site $335: 1.6-1.4 \mathrm{~cm} / \mathrm{yr}$. The spreading rate calculated from all biostratigraphic data is $1.15 \mathrm{~cm} / \mathrm{yr}$ (Figure 7).

\section{ACKNOWLEDGMENTS}

This investigation was supported through the German National Science Foundation (IPOD) and the National Science Foundation of America. I thank the shipboard scientific party of Leg 37 for collection of the samples. Drafting was done by H. Lacroix.

\section{REFERENCES}

Berggren, W.R., 1972. A Cenozoic time-scale-some implications for regional geology and paleobiogeography: Lethaia, v. 5, p. 195-215.

Cox, A., 1969. Geomagnetic reversals: Science, v. 163, p. 237-245.

Burckle, L.H., 1972. Late Cenozoic planktonic diatom zones from the eastern equatorial Pacific: Nova Hedwigia, Beihft., v. 39, p. 217-246.

Schrader, H.-J., 1973a. Proposal for a standardized method of cleaning diatom bearing deep-sea and land-exposed marine sediments: Nova Hedwigia, Beihft., v. 45, p. 403409.

1973b. Stratigraphic distribution of marine Denticula species in Neogene North Pacific sediments: Micropaleontology, v. 19, p. 417-430.

1974. Cenozoic marine planktonic diatom biostratigraphy of the tropical Indian Ocean. In Fisher, R., Bunce, E., et al., Initial Reports of the Deep Sea Drilling Project, Volume 24: Washington (U.S. Government Printing Office), p. 887-967.

Schrader H.-J. and Burckle, L.H., (in press). Marine diatom biostratigraphy, its correlation to other microfossil zonations and to the paleomagnetic record. In Riedel, W.R., Saito, T. (Eds.), Symposium Marine Plankton and Sediments: New York (Micropaleontology Press).

Vincent, E., 1974. Cenozoic planktonic biostratigraphy and paleo-oceanography of the tropical western Indian Ocean. In Fisher, R., Bunce, E., et al., Initial Reports of the Deep Sea Drilling Project, Volume 24: Washington (U.S. Government Printing Office), p. 1111-1150.

TABLE 2

Diatom Zonations Used in the Present Paper and Numbers of Cores and Sections Assigned to Rad Zone (Shaded Areas Indicate Basement)

\begin{tabular}{|c|c|c|c|c|c|c|c|}
\hline Diatom Zones (Burckle.1972) & $332+332 A$ & $332 \mathrm{~B}$ & $333+333 A$ & 334 & 335 & & \\
\hline Pseudoeunotia doliolus & & & & & 1 & \multicolumn{2}{|c|}{ Pleistocene } \\
\hline Rhizosolenia praebergonii & & $1-1 / 1-5$ & $2-1 / 4-4$ & & & \multirow{2}{*}{\multicolumn{2}{|c|}{ Pliocene }} \\
\hline Nitzschia jouseae & $1-1 / 2-2$ & & $4-4<6-1$ & & & & \\
\hline Thalassiosira convexa & $2-3 / 5-5$ & & & & & \multirow{4}{*}{ ț } & \multirow{6}{*}{ 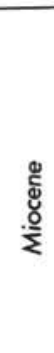 } \\
\hline Nitzschia miocenica & & & & & & & \\
\hline Nitzschia porteri & & & & $4-1 / 8-1$ & & & \\
\hline Coscinodiscus yabei & & & & $8-2 / 13-4$ & & & \\
\hline Cussia paleacea & & & & & 5 & \multirow{2}{*}{$\frac{\stackrel{0}{\frac{7}{0}}}{\frac{8}{\Sigma}}$} & \\
\hline Denticula nicobarica & & & & & & & \\
\hline
\end{tabular}



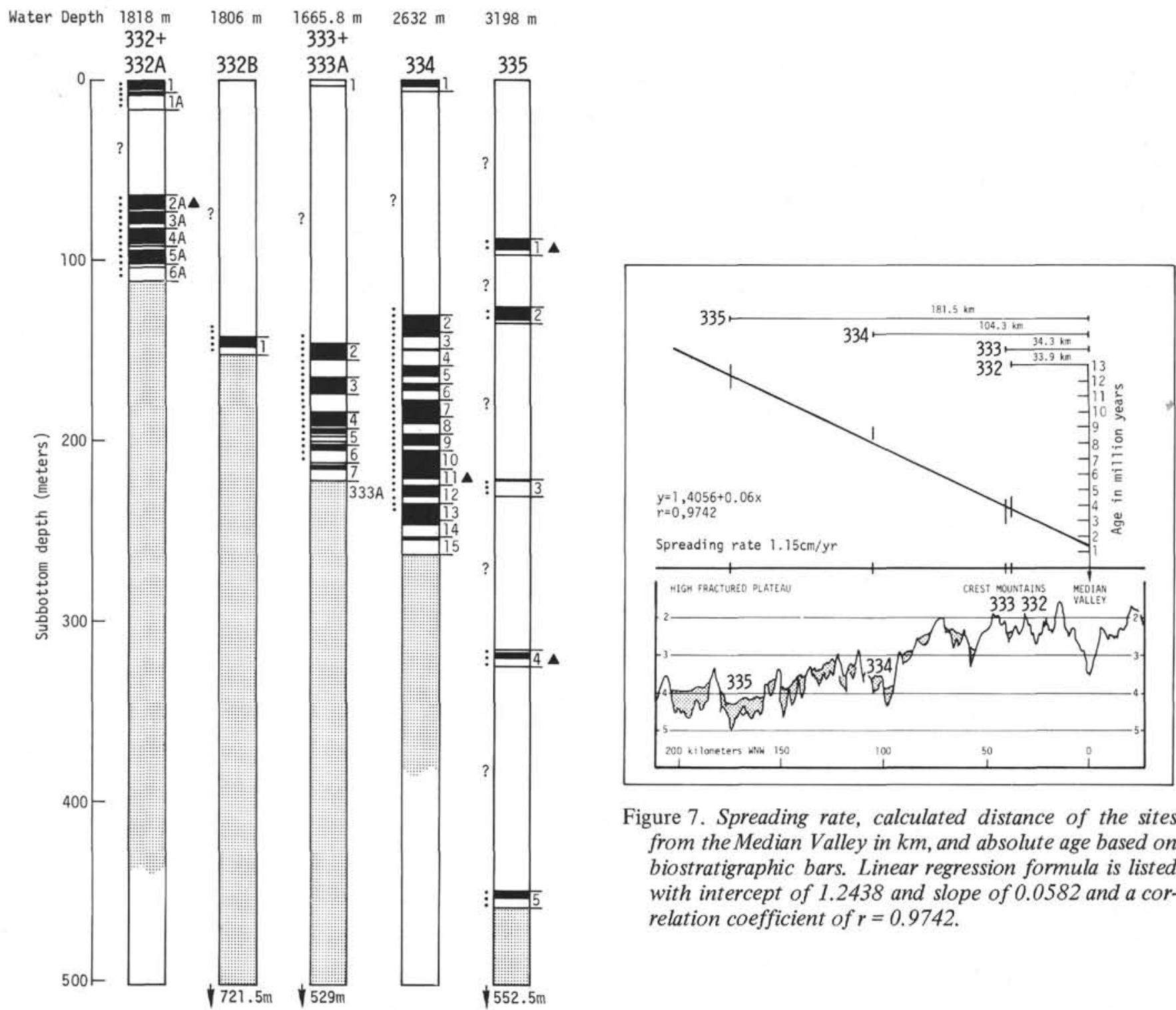

Figure 7. Spreading rate, calculated distance of the sites from the Median Valley in $\mathrm{km}$, and absolute age based on biostratigraphic bars. Linear regression formula is listed with intercept of 1.2438 and slope of 0.0582 and a correlation coefficient of $r=0.9742$.

Figure 6. DSDP Leg 37 drill holes. Black zones show recovery, numbers on right side are core numbers. Dotted line represent occurrences of diatoms, and question mark means no data available. Black triangles indicate occurrences of displaced fresh-water diatoms. Dotted areas indicate basement. 